Anna Rogozińska-Pawełczyk ${ }^{1}$

\title{
Rozdział V
}

\section{Zatrudnienie w kontekście tymczasowego kontraktu psychologicznego}

\section{Wprowadzenie}

Funkcjonowanie człowieka w pracy obejmuje podejmowanie decyzji, wykonywanie czynności pracy oraz osiąganie wyników w określonych ramach czasowych. Wszystkie wspomniane elementy aktywności człowieka są obecne w każdym rodzaju pracy, lecz praca w warunkach tymczasowego zatrudnienia stawia tymczasowym pracownikom odmienne wymagania w odniesieniu do powyższych elementów pracy. W tym aspekcie pojawiają się nowe kategorie opisu i wyjaśniania zachowań ludzkich w procesie pracy, ponieważ zmieniają się warunki zatrudnienia. Czasowe zatrudnienie jest jedną z najbardziej charakterystycznych zmian w obecnych czasach w odniesieniu do zachodzących relacji pomiędzy pracownikiem a pracodawcą, określanych jako tymczasowy kontrakt psychologiczny.

Rozważania nad tymczasowym kontraktem psychologicznym koncentrują się wokół specyficznych kierunków przeobrażeń, niesformalizowanych relacji, wzajemnych zobowiązań i oczekiwań odnoszących się do różnych aspektów sytuacji pracy oraz organizacyjnego funkcjonowania trójstronnej relacji zawodowej.

W rozdziale podejmowany jest problem tymczasowego kontraktu psychologicznego zawieranego pomiędzy trzema stronami: agencją pracy tymczasowej, pracownikiem tymczasowym a organizacją - użytkownikiem. Akcent położony jest na wskazanie istotnych cech charakteryzujących zachodzące trójstronne relacje w tymczasowym kontrakcie psychologicznym. Dokonano zaprezentowania procesu formowania i funkcjonowania tymczasowego kontraktu psychologicznego. Następnie podjęte zostało zagadnienie powszechności zmieniającego się paradygmatu kontraktu psychologicznego z relacyjnego na transakcyjny, wpisujący się w specyfikę tymczasowego zatrudnienia. W dalszej części rozdziału skupiono się na psychologicznych aspektach funkcjonowania człowieka w warunkach tymczasowego zatrudnienia, ze szczególnym uwzględnieniem satysfakcji z pracy oraz ponoszonych przy tym kosztach psycholo-

${ }^{1}$ Adiunkt, Katedra Pracy i Polityki Społecznej, Instytut Ekonomik Stosowanych i Informatyki, Wydział Ekonomiczno-Socjologiczny, Uniwersytet Łódzki. 
gicznych. Rozważania koncentrują także uwagę na analizie doświadczania ram czasowych tymczasowego kontraktu psychologicznego przez pracowników tymczasowo zatrudnionych.

\section{Tymczasowy kontrakt psychologiczny}

Zatrudnienie tymczasowe jest formą zatrudnienia, w której oprócz umów biznesowych zawierane są trzy niepisane relacje międzyludzkie w postaci kontraktu psychologicznego - ze względu na swój charakter zwany tymczasowym. Tymczasowy kontrakt psychologiczny stanowi zbiór specyficznych, oczekiwań i zobowiązań powstających między trzema stronami. Umowa oparta na kontrakcie psychologicznym, podobnie jak kontrakt biznesowy obejmuje wzajemne oczekiwania wszystkich trzech stron wchodzących w skład relacji, zmiany tych oczekiwań w czasie oraz ich wpływu na zachowanie ${ }^{2}$.Stanowi on niepisaną umowę wymiany, wszystkich trzech stron: agencji pracy tymczasowej, pracodawcy - użytkownika i pracownika. Trzy podmioty posiadają względem siebie oprócz wspomnianych indywidualnych oczekiwań także i określone zobowiązania ${ }^{3}$. Tymczasowy kontrakt psychologiczny koncentruje się na konsekwencji realizacji zadeklarowanych zobowiązań zawodowych i wypełnianiu obowiązków pracowniczych przez poszczególne strony relacji ${ }^{4}$. Innymi słowy, to zespół przekonań ludzi co do warunków i zasad realizacji uzgodnień, przyrzeczeń i obietnic w odniesieniu do pracy oraz wynikających z nich korzyści i strat stojących zarówno po stronie agencji pracy tymczasowej i pracodawcy - użytkownika, jak i po stronie tymczasowego pracobiorcy.

Specyfika trójstronnej relacji zachodzącej między pracownikiem, agencją pracy tymczasowej a pracodawcą - użytkownikiem opartej na kontrakcie psychologicznym charakteryzuje się kilkoma właściwościami:

- pierwszym elementem jest schemat poznawczy, który organizuje w jedną całość powiązane treściowo elementy, a zarazem nadaje im znaczenie i wartość. Wchodząc w trójstronne relacje każda ze stron zaczyna tworzyć pewne wyobrażenia na temat organizacji i ludzi tworzących kontrakt psychologiczny. Stosunek do osoby, której strona relacji nie poznała do tej pory osobiście, kształtuje się na podstawie ograniczonej wiedzy na jej temat - nawet jeśli wiedza ta jest wyłącznie wytworem wyobraźni. Elementy tego schematu mogą być w różnej mierze podzielane przez osoby, co skutkuje niejednoznacznością przypisywanych znaczeń i wartości;

- drugą istotną cechą tymczasowego kontraktu psychologicznego jest regulacja zachowania. Kontrakt psychologiczny generuje oczekiwania i stanowi zobowią-

2 Rousseau D. M., Tijoriwala, S., Assessing psychological contracts: issues, alternatives and measures. Journal of Organizational Behavior, 1998, s.121-139.

3 Por. Schein V.E., Maurer E.H., Novak J.F., Impact of flexible working hours on flexibility. Journal of Applied Psychology, 1977, 62, 463-465, za: Armstrong M, Zarządzanie zasobami ludzkimi, Wolters Kluwers, Kraków, 2007, s. 181.

${ }^{4}$ Cullinane, N., Dundon, T., The psychological contract: A critical review. International Journal of Management Reviews, 2006, 8 (2), s. 113-129; Rousseau D.M., Schema, promises and mutuality: the building blocks of the psychological contract. Journal of Occupational and Organisational Psychology, 2001, 74 (4), s. 511-541. 
zanie do podejmowania określonych działań, a w konsekwencji wyznacza sposób regulacji wzajemnych stosunków;

- kolejną charakterystyczną własnością są uczucia generujące odczucie o charakterze pobudzenia pozytywnego lub negatywnego związanych z nawiązywaniem i wchodzeniem w relacje interpersonalne. Ich intensywność, powierzchowność oraz charakter odzwierciedla stosunek jednostki do stron zachodzących relacji. Choć odczucia mogą zmieniać się w czasie, to w relacjach nie przestają być obecne; - następna prawidłowość opiera się na niekompletności kontraktu psychologicznego, który jest trwałym elementem zawieranych zobowiązań, często trudnych do zwerbalizowania i wyegzekwowania. Opiera się bowiem na wymianie oczekiwań dotyczących sfery emocji i zachowań, a więc tymczasowy kontrakt psychologiczny jest $w$ tym miejscu rozpatrywany w kategoriach czysto niematerialnej, nieformalnej umowy, która nie została spisana i w wielu miejscach jest niejasna i niedoprecyzowana ${ }^{5}$;

- jeszcze jedną ważną cechą tymczasowego kontraktu psychologicznego jest zmienność jego charakteru. Raz sformułowany kontrakt nie będzie miał jednak trwałego charakteru. Będzie się znajdował w stanie permanentnej zmiany i rewizji, jednocześnie stanowiąc główne spoiwo relacji pomiędzy trzema stronami stosunku pracy. Jego zmienność upatrywana jest w reakcji na stale zmieniające się warunki otoczenia, które są spowodowane nietrwałością relacji zachodzącej po stronie zmieniających się pracodawców użytkowników a pracownikami. Za zmienny charakter tymczasowego kontraktu psychologicznego odpowiada także inna tendencja związana ze wzrostem znaczenia elastyczności i zdolności do adaptacji. Z uwagi na zwiększenie się niestabilności zatrudnienia, tymczasowy kontrakt psychologiczny według Hiltropa nabiera cech sytuacyjnych, krótkoterminowych i zakłada, że przetrwanie i rozwój każdej ze stron jest w mniejszym stopniu zależny od każdej z osobna ${ }^{6}$.

W ocenie kontraktu psychologicznego Guest wezwał do badania kontraktu psychologicznego jako dwukierunkowej wymiany i włączenia punktu widzenia pracodawcy i pracownika ${ }^{7}$. Oczekiwania i zobowiązania powstające na kanwie tymczasowego kontraktu psychologicznego posiadają cechy trójbiegunowe ${ }^{8}$. Pracownik ma określone lecz subiektywne oczekiwania względem organizacji a organizacja względem pracownika. Również określone oczekiwania stawia sam pracownik agencji pracy tymczasowej. Pracownicy tymczasowo zatrudniani często nie wiedzą, czego tak naprawdę oczekują od organizacji użytkownika oraz od agencji pracy tymczasowej, nie są też do końca świadomi tego, co mogą im w zamian zaoferować. W podobnej sytuacji są także

5 Rogozińska-Pawełczyk A., Impact and effects of relational and transactional psychological contract. Slovak Scientific Journal Management: Science and Education, Faculty of Management Science and Informatics, University of Žilina, 2012, 1(1), s. 41.

${ }^{6}$ Hiltrop J. M., The changing psychological contract: the human resource challenge of the 1990s, European Management Journal, 1995, 13(30), s. 286.

7 Guest D., Flexible employment contracts, the psychological contract and employee outcomes: an analysis and review of the evidence. International Journal of Management Reviews, 2004,5/6, s. 1-19.

8 Rousseau D. M., Tijoriwala, S. op.cit., s. 121-139. 
agencja pracy tymczasowej oraz pracodawcy - użytkownicy. Wszystko co kierownictwo obu pracodawców robi lub uważa, że robi (podejmowane działania w aspekcie polityki personalnej), wpływa na postawy i zachowania pracowników tymczasowych w postaci zwiększenia lub zmniejszenia poziomu: satysfakcji z pracy, zaangażowania, przynależności organizacyjnej, motywacji do pracy, czy poczucia lojalności, zaufania, sprawiedliwego traktowania oraz ponoszenia kosztów psychologicznych z wykonywanej pracy ${ }^{9}$.

\section{Nowy paradygmat kontraktu psychologicznego}

Wizja człowieka pracującego tymczasowo oraz aktualne przemiany występujące na rynku pracy stanowią istotne czynniki wywołujące zmianę konstrukcji kontraktu psychologicznego, co w rezultacie pozwala wyodrębniać różne jego rodzaje. Typologia zaproponowana przez Rousseau opiera się na dwu wymiarach kontraktu ${ }^{10}$ :

- charakterze formalnej umowy, określającej ramy czasowe trwania zatrudnienia (krótkoterminowe i długoterminowe lub zawarte na czas określony, bądź nieokreślony);

- stopniu przewidywalności otrzymywania gratyfikacji (przypadkowe, a zatem realizowane nieplanowo lub na podstawie mało czytelnych reguł oraz nieprzypadkowe, czyli oparte na jasno określonych zasadach wymiany).

- Rousseau wyróżniła następujące typy kontraktu psychologicznego:

- kontrakt relacyjny, którego istotą jest wymiana pracowniczej lojalności wobec organizacji i zaangażowania w realizowanie jej potrzeb i interesów, w zamian za bezpieczeństwo zatrudnienia, utożsamiane z perspektywą tworzoną przez zawarcie umowy o pracę na czas nieokreślony oraz możliwością realizowania kariery wewnątrzorganizacyjnej. W relacyjnym kontrakcie psychologicznym pracodawca oferuje pracownikowi możliwość realizowania kariery zawodowej wraz z instrumentami umożliwiającymi jej realizowanie. Gratyfikacje uzyskiwane przez pracownika zależą przede wszystkim od faktu członkostwa w organizacji i są przez nią jednostronnie kształtowane, dość słabo natomiast są powiązane $z$ indywidualnymi osiągnięciami w pracy;

- kontrakt zrównoważony, którego istotę stanowi wymiana zaangażowania i lojalności pracownika na perspektywę bezpiecznego zatrudnienia, tworzoną nie tyle z tytułu zawarcia długookresowej umowy o pracę, ile raczej przez stwarzanie warunków umożliwiających rozwój kompetencji zawodowych, czyli kształtowanie tzw. zatrudnialności. Gratyfikacje uzyskiwane przez pracownika są uzależnione od jego osiągnięć zawodowych, konfrontowanych z rosnącymi wymaganiami w tym zakresie;

- kontrakt transakcyjny, będący wymianą krótkookresowego zaangażowania pracownika w zaspokajanie potrzeb organizacji (co najczęściej sprowadza się do realizowania wyspecjalizowanych zadań) na możliwości budowania własnej za-

9 Conway, N., Briner, R. B., Understanding Psychological Contract at Work, OUP, Oxford, 2002, s. 287-302.

10 Rousseau D, M., Psychological Contracts in Organizations: Understanding Written and Unwritten Agreements, Sage, Thousand Oaks-London, 1995, s. 98. 
trudnialności oraz realizowania osobistych celów zawodowych. Gratyfikacje, jakie uzyskuje w takiej sytuacji pracownik, jednoznacznie wynikają z formalnych aspektów zawartej umowy i są łatwo przewidywalne;

- quasi-kontrakt przejściowy, charakteryzujący się głębokim brakiem zaufania pracowników do zatrudniającej ich organizacji, spowodowanym coraz mniejszą liczbą uzyskiwanych przez nich gratyfikacji oraz niepewnością co do przyszłych działań pracodawcy, który często manipuluje informacją. Trwanie pracowników w warunkach quasi-kontraktu przejściowego ma najczęściej charakter wymuszony sytuacyjnie i wynika z braku innych możliwości zarobkowania; gratyfikacje uzyskiwane przez pracowników cechują się niskim stopniem przewidywalnościi W swojej istocie kontrakt psychologiczny jest pojęciem wskazującym na charakter relacji pracodawca - pracownik. W ostatnim czasie relacje te ulegają istotnym zmianom kształtowanym głównie przez elastyczne formy zatrudnienia. Coraz częściej odnaleźć można przykłady osób, które nie poszukują w firmie przede wszystkim bezpieczeństwa zatrudnienia oraz firm, które widzą swój związek z pracownikiem na zasadzie czasowo ograniczonego kontraktu uzależnionego od realizacji celów. W znacznej mierze, kontrakt psychologiczny jest ugruntowany na opcji zakładającej niezależność rozwoju zawodowego pracownika, który jest kreatorem własnej kariery, ponosząc za nią pełną i niezbywalną odpowiedzialnośćc ${ }^{2}$. Percepcja kontraktu psychologicznego przez pracowników tymczasowych staje się więc podstawowym zagadnieniem dotyczącym pracowników zatrudnianych w tymczasowych formach zarobkowania.

\section{Formowanie i funkcjonowanie tymczasowego kontraktu psychologicznego}

Zakres tymczasowego kontraktu psychologicznego pomiędzy agencją pracy tymczasowej, pracodawcą użytkownikiem a pracownikiem jest efektem precyzowania wzajemnej oferty stron. Jego formowanie się przebiega w pięciu fazach, gdzie dwie pierwsze dotyczą dwustronnej relacji agencja pracy tymczasowej a pracownik tymczasowy, natomiast kolejne odzwierciedlają już trójstronny charakter tymczasowego kontraktu psychologicznego ${ }^{13}$.

Pierwszy etap, tzw. faza wstępna zawierania tymczasowego kontraktu psychologicznego ma charakter dwubiegunowy, dotyczący agencji pracy tymczasowej oraz kandydata na pracownika tymczasowego. Indywidualne oczekiwania potencjalnego tymczasowego pracownika są kształtowane jeszcze przed jego zatrudnieniem w APT. Wpływa na nie przede wszystkim otoczenie makroekonomiczne związane z aktualnym kształtem rynku pracy oraz normy zawodowe definiujące społeczne oczekiwania względem realizacji zadań w obrębie danego wakatu i związane z nimi wartości oraz wynikające z nich prawa i zobowiązania.

11 Bohdziewicz P., Kariery zawodowe w gospodarce opartej na wiedzy (na przykładzie grupy zawodowej informatyków), Wydawnictwo UŁ, Łódź, 2008, s. 115-122.

12 Rogozińska-Pawełczyk A., Od relacyjnego do transakcyjnego kontraktu psychologicznego - zmieniający się paradygmat, Zarządzanie Zasobami Ludzkimi, 3-4, 2011, s. 61-77.

13 Rousseau D.M. op.cit., s. 511-541. 
W fazie zatrudnienia, następuje wymiana informacji dotyczących zakresu potencjalnych praw i obowiązków, możliwości zatrudnienia u potencjalnych pracodawców użytkowników oraz ocena wzajemnie wysłanych sygnałów. Po zawarciu formalnej umowy o pracę z agencją pracy tymczasowej, następuje kolejna, trzecia faza formowania tymczasowego kontraktu psychologicznego, zachodząca w momencie wynajęcia pracownika tymczasowego od agencji przez organizację użytkownika. W tym miejscu z dwubiegunowej relacji pracownik - agencja pracy tymczasowej pojawia się trójstronny charakter tymczasowego kontraktu psychologicznego.

Wchodząc w świat nowej, kolejnej pracy u pracodawcy - użytkownika, każdy pracownik tymczasowy wnosi osobisty zestaw wartości, kompetencji, wiedzy, norm społecznych, schematów poznawczych, nawyków, przyzwyczajeń i ekspresji cech indywidualnych. Przekonania zbudowane na podstawie uprzednich doświadczeń zawodowych, z jakimi rozpoczyna pracę dana osoba, mogą diametralnie się różnić od stanu faktycznego. Stąd nawet w ramach jednej organizacji, poziom realizacji kontraktu psychologicznego poszczególnych jej uczestników (tymczasowych i stałych) również może być oceniany odmiennie, nawet jeśli wszyscy podlegają tym samym zasadom ogólnym. Jeśli nowy tymczasowy pracownik właściwie odczyta wartości, normy, schematy postępowania, nawyki i rytuały składające się na obraz kultury organizacyjnej w firmie pracodawcy - użytkownika, może rozpocząć współdziałanie i uczestnictwo w nowej grupie. Tymczasowy kontrakt psychologiczny zawierany w momencie wynajęcia od agencji przez organizację użytkownika pracownika, buduje jedynie niewielkie zaangażowanie i wysiłek ze strony pracownika nie wykraczający poza zakres jego obowiązków ${ }^{14}$.

W zależności od zmian zawieranych relacji pracodawcę - użytkownika i pracownika tymczasowego pojawia się cykliczność trzeciej, czwartej i piątej fazy. Kształtowanie się tymczasowego kontraktu psychologicznego w organizacji użytkownika, zaczyna się od fazy czwartej, tzw. wczesnej socjalizacji, czyli poszukiwania informacji odnoszących się do realizacji określonych praktyk w firmie dzięki bezpośrednim relacjom ze współpracownikami i przełożonym. W tym czasie następuje krystalizowanie się i stabilizowanie określonych oczekiwań a także przez spadek intensywności poszukiwania informacji (tzw. późniejsze doświadczenia) Wczesna socjalizacja kończy się oceną, czyli potwierdzaniem dokonanych wcześniej uzgodnień i ustabilizowanych wyobrażeń o wzajemnych zobowiązaniach, lub chęcią rewizji i renegocjowania warunków kontraktu, w przypadku naruszenia ustalonych reguł. Trójstronność relacji pomiędzy agencją pracy tymczasowej, firmą - użytkownikiem a pracownikiem tymczasowym kończy faza piąta nazywana rewizyjną, następująca w momencie wygaśnięcia zawartej umowy między agencją pracy tymczasowej a organizacją użytkownikiem. Następuje w tym miejscu automatyczny powrót do fazy drugiej formowania się tymczasowego kontraktu psychologicznego, która wzbogacana jest z czasem o elementy renegocjacji i modyfikacji warunków kontraktu ${ }^{15}$.

14 Fieldman D., Doerpinghaus H., Turnley W., Managing Temporary Workers: A Permanent HRR Challange, Organizational Dynamics, 1994, 23, s. 62.

15 Guest D., op.cit., s. 1-19. 


\section{Satysfakcja z pracy tymczasowej}

To, jaką formę przyjmie kontrakt psychologiczny i jakie zawiera treści jest nierozerwalnie związane z przeżywaniem, bądź nie przeżywaniem satysfakcji z pracy. Satysfakcja z pracy to ogólny stan zadowolenia pracownika, poczucie czegoś pozytywnego, przekonanie, że sprawy związane z pracą w danej firmie idą w dobrym kierunku, $a$ istniejące problemy są możliwe do rozwiązania. Satysfakcja powstaje w odpowiedzi na właściwości wykonywanej pracy tymczasowej. To, jak układa się współpraca z przełożonymi, czy i jakie potrzeby zaspokaja pracownikom praca tymczasowa wpływa na odczuwane bądź nie odczuwane zadowolenie z jej wykonywania.

Specyfika zatrudnienia tymczasowego w swojej naturze ma związek ze zmiennością miejsca pracy. Wiążą się z tym cykliczne zachwiania równowagi między pracownikiem a organizacją - użytkownikiem oraz permanentna destabilizacja relacji zawodowych. Satysfakcja z pracy okupiona psychologicznymi kosztami pracy może stanowić satysfakcję pracownika z własnej zaradności związanej ze sprawnym funkcjonowaniem w trudnych warunkach.

Wiele badań nad tymczasowym kontraktem psychologicznym, oscylowało do tej pory wokół skutków naruszenia lub realizacji tych kontraktów. Wykazały one także, że postrzegane spełnienie kontraktu psychologicznego znacząco wpływa na postawy i zachowania pracowników, takie jak poziom satysfakcji z pracy ${ }^{16}$.

Pfeffer i Baron potwierdzili w swoich badaniach, że im stabilniejszy kontrakt psychologiczny, tym wyższy poziom odczuwanej satysfakcji z pracy tymczasowej. Nieelastyczny i nie dynamiczny kontrakt psychologiczny wymaga zatem każdorazowej renegocjacji pracownika w dostosowywaniu się do zmian w otoczeniu. Ze względu na naturę stanowisk czasowych, gdzie są one tworzone są po to, by uniknąć dwuznaczności i ułatwić zachodzące na nim zmiany osobowe ${ }^{17}$, wykonywanie obowiązków zawodowych w warunkach zatrudnienia tymczasowego odbywa się w oparciu o standardowe procedury. Ze względu na czasowy okres trwania umowy, tymczasowe kontrakty psychologiczne nie ewoluują, czego konsekwencją jest spadek zaufania w relacjach zawodowych i wzrost odczuwanej niepewności w organizacji ${ }^{18}$.

W warunkach pracy tymczasowej przedmiotem wymiany kontraktu psychologicznego są klarowne i jasno określone, jednoznacznie zdefiniowane warunki pracy, które sprzyjają odczuwanej satysfakcji z pracy. Kontrakty jasno określone, choć prowadzą do zmniejszenia potencjalnej szansy na wszelkie odstępstwa i naruszenia wa-

16 Por. Cuyper, N., DeWitte, H., The impact of job insecurity and contract type on attitudes, well-being and behavioural reports: A psychological contract perspective. Journal of Occupational and Organizational Psychology, 2006,79, (3), s. 395-409; Raja U., Johns, G., Ntalianis, F., The impact of personality on psychological contracts. Academy of Management Journal, 2004, 47 (3), s. 350-367; Sutton, G., Griffin, M., Integrating expectations, experiences and psychological contract violations: A longitudinal study of new professionals. Journal of Occupational and Organizational Psychology, 2004, 77, s. 493-514.

17 Pfeffer J., Baron J., N., Talking the workers back out: Recent trends in the structure of employment. In: Cummings L. L., Staw B. M., (Eds.), Research in Organizational Behavior, Rights and Responsibilities Journal, 1988, 2, s. 121-139.

18 McLean Parks J., Kidder D. L., Gallagher D. G., Fitting square pegs into round holes: mapping the domain of contingent work arrangements onto the psychological contact. Journal of Organizational Behavior, 1998, 19, s. 697-730. 
runków umowy mają też swoje negatywne konsekwencje ${ }^{19}$. Jasno sprecyzowane cele wpływają na zmniejszenie spontaniczności i innowacyjności, nawet jeśli wpływają one na wzrost efektywności. McLean Parks zauważył że pracownicy o przejrzystych kontraktach psychologicznych niechętnie współpracowali z innymi w celu realizacji założonych celów, gdyż współpraca ta nie była ściśle określona w kontrakcie. Sama specyfika pracy tymczasowej przez swoją „wymienność" kadry i czasowy charakter pracy, wprowadza konieczność jasno określonych kontraktów psychologicznych, co związane jest z doświadczaniem satysfakcji z przedmiotowej pracy ${ }^{20}$.

Badania nad zatrudnieniem tymczasowym sugerują, że rozbieżność w odczuwaniu satysfakcji z pracy może mieć swoje źródło w dokonywanej samoocenie ${ }^{21}$. Osoby z pozytywną oceną samej siebie miały większą satysfakcję z pracy wyżej niż pracownicy tymczasowi z mniej pozytywnymi samoocenami. Podczas zgłębiania tej problematyki, Judge, Locke, Durham i Kluger odkryli, że relacja między dokonywaną samooceną a satysfakcją z pracy tymczasowej była uwarunkowana postrzeganiem aspektów pracy: tożsamość, różnorodność, informację zwrotną, autonomię i znaczenie ${ }^{22}$.Osoby z pozytywnymi samoocenami oceniały pracę tymczasową wyżej i dlatego też były bardziej zadowolone z pracy. Relacja między samooceną a aspektami pracy może być wynikiem samego procesu percepcyjnego. To znaczy, że jednostki o pozytywnych samoocenach mogą widzieć swoje tymczasowe zatrudnienie jako niosące większe wyzwania, ponieważ jednostki te mają predyspozycje do tego, aby pozytywnie postrzegać wszystkie aspekty swojej pracy.

Inne badania nad powiązaniami między samoocenami a aspektami pracy wskazują iż pozytywnie nastawieni pracownicy tymczasowi doświadczają bardziej obiektywnych wydarzeń pozytywnych w ich życiu, podczas gdy negatywnie usposobieni pracownicy tymczasowi doświadczają bardziej negatywnych wydarzeń ${ }^{23}$. Dlatego też Diener, Larsen i Emmons postawili w swoich badaniach wniosek wskazujący, osoby dokonujące pozytywnej samooceny będą bardziej skore do wyboru tymczasowego zatrudnienia o wyższym stopniu wyzwań, niż osoby o negatywnym obrazie samych siebie, które będą koncentrować się na trudnościach oraz potencjalnie możliwych porażkach podczas wykonywania pracy tymczasowej związanej z wysokimi wyzwaniami i dlatego właśnie będą jej unikać.

Wiele prowadzonych badań wskazało, że odczuwany poziom satysfakcji z pracy jest powiązany z usposobieniem danej osoby ${ }^{24}$. Pracownicy tymczasowi pozytywnie usposobieni oceniają charakter zadania lub pracy tymczasowej jako bardziej satysfak-

\footnotetext{
19 Rousseau D.M., Parks J. M., The contract of individuals and organizations. In: Cummings L. L., Staw B. M., (red.), Research in organizational behavior, Greenwich, CT: JAI Press, 1993, 15, s. 1-47.

20 McLean Parks J., Kidder D. L., Gallagher D. G., op.cit., s. 697-730.

21 Judge T.A., Locke E.A., Durham C.C., Kluger A.N., Dispositional Effects on Job and Life Satisfaction: The Role of Core Evaluations, Journal of Applied Psychology ,1998, 83, s. 17-34.

22 Judge T.A., Locke E.A., Durham C.C., Kluger A.N., op.cit., s. 17-34.

23 Diener E., Larsen R.J., Emmons R.A., Person \& Situation interactions: Choice of situations and congruence response models. Journal of Personality and SocialPsychology,1984, 47, s. 580-592.

24 Por. Diener E., Larsen R.J., Emmons R.A., op.cit., s. 580-592; Judge T.A., Locke E.A., Durham C.C., Kluger A.N., op.cit., s. 17-34.
} 
cjonujący ${ }^{25}$. Wyniki badań potwierdzają też powiązanie pomiędzy posiadanymi cechami osobowości a indywidualnym postrzeganiem aspektów pracy. Pracownicy tymczasowi mający tendencje do doświadczania emocji pozytywnych, reagują pozytywnie na sytuacje mające na celu wywołanie pozytywnego wpływu, podczas gdy osoby o negatywnych samoocenach są mniej skłonne do reagowania pozytywnie na takie sytuacje ${ }^{26}$.Dokonywane samooceny wywierają wpływ na satysfakcję z pracy przez generalizowanie własnych pozytywnych uczuć pracownika tymczasowego, co przekłada się na pozytywne kształtowanie kontraktu psychologicznego oraz pozytywny odbiór pracy tymczasowej.

Istotnym elementem wpływającym na odczuwany poziom satysfakcji z pracy jest wykonywanie przez pracownika tymczasowego obowiązków na rzecz dwóch pracodawców, czyli istnienia podwójnych zobowiązań wobec APT i firmy - użytkownika ${ }^{27}$. Cykliczne zmiany zawieranych relacji międzyludzkich mogą uniemożliwić pracownikowi wypełnianie obowiązków zawartych w kontrakcie psychologicznym. Takie mnogie związki implikują do stwierdzenia, że jeden pracownik mający więcej niż jednego szefa, posiada sprzeczne dążenia wynikające z różnic w oczekiwaniach pomiędzy dwoma relacjami zawodowymi, co w konsekwencji prowadzić może do zmniejszenia poziomu pewności siebie, samooceny, motywacji i satysfakcji z pracy. Fakt ten wpływa również na zbyt duże obciążenie obowiązkami oraz zwiększone koszty psychologi$\mathrm{cze}^{28}$. Pracownik tymczasowy czerpie zadowolenie i korzyści z utrzymywania licznych ról, jedynie wtedy, gdy role te są jasno sprecyzowane i nie nakładają się na siebie.

Satysfakcja z pracy odczuwana przy licznych związkach ze stronami umów może zmniejszać ryzyko pozostawania bez pracy, czy wykonywania zleceń nie do końca odpowiadających oczekiwaniom pracownika. Poza tym, warunki umowy zawieranej między agencją pracy tymczasowej a firmą - użytkownikiem są skonstruowane w taki sposób, aby zmniejszyć ryzyko „złego wykonania” zlecenia i ograniczyć potencjalny wpływ na dalsze zatrudnienie tymczasowe ${ }^{29}$.

\section{Koszty psychologiczne w tymczasowych formach zatrudnienia}

Specyfika tymczasowego kontraktu psychologicznego polega głównie na cyklicznej zmianie firmy - użytkownika. Analizując sytuację pracownika tymczasowo zatrudnionego można się w niej doszukać aspektów wszystkich wymienionych przez psychologów sytuacji trudnych, w których pracownik podejmuje aktywność zarad-

25 Brief A., Burke M., George J., Robinson B., Webster J., Should Negative Affectivity Remain an Unmeasured Variable in the Study of Job Stress?, Journal of Applied Psychology", 1988, 73, s. 193-198.

26 Larsen R.J., Ketelaar T., Personality and susceptibility to positive and negative emotional states. Journal of Personality and Social Psychology, 1991, 61, s. 132-140.

27 Rogers J.K., Just a temp: experience and structure of alienation in temporary clerical employment, Work and Occupations, 1995, 22( 2), s. 137-166.

28 Tilly Ch., Reasons for the Continuing Groth in Part-Time Employment. MonthlyLabourReview, 1991, 3, s. 10-19. 14, s. 57-74.

29 Eisenhardt K., Agency theory: An assessment and review. Academy of Management Review, 1989, 
czą, której z kolei towarzyszą nieprzyjemne, przykre odczucia- koszty psychologiczne. Koszty psychologiczne są przykrymi negatywnymi emocjami, jakie jednostka odczuwa, nie akceptując rozbieżności między oczekiwaniami a rzeczywistością. Koszty stanowią skutek rozbieżności oraz działań, których celem jest redukcja tej rozbieżności ${ }^{30}$. Owe przykrości (dyskomforty) pojawiają się w trakcie działania oraz po jego zakończeniu jako pewnego rodzaju refleksja skojarzona z emocjami negatywnymi. Tymczasowy kontrakt psychologiczny jest więc, jak zresztą każdy kontrakt związany z pracą, równocześnie związany z „zapłatą" zarówno za sukces, jak i porażkę.

Działania podejmowane $w$ celu zlikwidowania sytuacji stresowej, $w$ tym zagrożenia, mogą wywoływać negatywne stany emocjonalne, dyskomforty psychiczne, ponieważ pracownik tymczasowy może nie akceptować takiej pracy, jaką obecnie wykonuje. Owe nieakceptowane działania, jak określiła Ratajczak, to tzw. „extra wydatki”, które mogą być przez pracownika tymczasowego różnie oceniane, mając wówczas do czynienia z różnymi treściami kosztów psychologicznych ${ }^{31}$. Ekstra wydatki mogą być oceniane jako nadmierne, czyli wymagane przez innych i odczuwane jako niesprawiedliwe i krzywdzące. Wówczas treścią dyskomfortu psychicznego jest poczucie krzywdy. Kolejne oceny są traktowane jako zbędne, niepotrzebne; wówczas treścią dyskomfortu jest poczucie winy. W przypadku ekstra wydatków określanych jako nieprzynoszące spodziewanych rezultatów, treścią dyskomfortu psychicznego jest rozczarowanie, i niespełniona nadzieja. Natomiast w ocenie niezgodnej z normą społeczną, np. „bycie uczciwym”, „zachowaniem twarzy", wówczas treścią dyskomfortu staje się poczucie wstydu) ${ }^{32}$.

Przykrości związane z ponoszeniem kosztów psychologicznych są wynikiem oceny działania, które obejmuje radzenie sobie w sytuacji stresu. Ocena ta polega na porównywaniu rzeczywistego działania z jego wzorem, który znajduje się w umyśle pracownika. Innymi słowy, osoba porównuje własne działanie zaradcze z jego wyobrażeniem i na tej podstawie je ocenia. Według Ratajczak pracownik ocenia własne działanie ze względu na sensowność, skuteczność, ekonomiczność, bezpieczeństwo oraz etyczność.

Działania zaradcze są określane jako niesensowne, wówczas gdy osoba podejmuje działanie z góry skazane na niepowodzenie, W przypadku pracy tymczasowej dzieje się tak, gdy pracuje na stanowisku, które wymaga od pracownika niższych kompetencji niż te, które posiada. W przypadku działań nieskutecznych pracownik może podejmować wysiłki związane ze zdobyciem zatrudnienia na czas nieokreślony w organizacji, w której dotychczas pracował realizując umowę z agencją pracy tym czasowej. Ocena działań jako nieekonomicznych może następować na przykład w sytuacji, gdy zamierzone efekty są osiągnięte nadmiernym kosztem (np. realizowane znacznym ograniczeniem kontaktów z rodziną). Koszty pracy związane $z$ bezpieczeństwem są brane pod uwagę $w$ przypadku narażenia na utratę cenionej przez pracownika wartości, na przykład zdrowia, pozycji społecznej. Takimi aspektami w pracy tymczasowej może być stygmatyzacja pracowników tymczasowych czy

30 Ratajczak Z., Wsparcie społeczne w warunkach zagrożenia funkcjonowania człowieka w środowisku pracy, Psychologiczne problemy funkcjonowania człowieka w sytuacji pracy, Uniwersytet Śląski, 1992 , 10, s. 19.

31 Jak wyżej, s. 19.
32 Jak wyżej, s. 20. 
względnie wysoka częstotliwość zrywania relacji interpersonalnych. Działania niezgodne z normami społecznymi i moralnymi będą oceniane przez pracowników tymczasowych jako nieetyczne w przypadku pojawienia się na przykład dylematu: czy oszczędzać papier ksero i gasić światło w organizacji, skoro jest się tylko przez tydzień jej pracownikiem?

W sytuacji gdy pracownik tymczasowy uzna, że jego działanie zaradcze wykazało braki w którymś z wymienionych aspektów, doznaje wtedy uczucia przykrości. Przykrości mogą być traktowane jako informacje zwrotne i wskazówki dotyczące tego, jak poprawić owo działanie (np. poprzez zmniejszenie pewnych nakładów). Wówczas przykrości te służą do doskonalenia działania w myśl zasady: „uczymy się na błędach"33. W wypadku, kiedy pracownik tymczasowy ocenia przykrości w kategoriach szkodliwych, zbędnych, wówczas może doświadczyć poczucia krzywdy, rozczarowania, poczucia winy i wstydu. Zatem przeżywane przykrości i dyskomforty mogą być rozpatrywane w kategoriach wskazówek, pewnego rodzaju błędów w procesie uczenia się, lub jako karaza podjęte działania.

Koszty psychologiczne stanowią ważny regulator ludzkiego działania. Z jednej strony przyczyniają się do zmniejszenia stresu ekonomicznego oraz zwiększenia skuteczności działania i powstania poczucia podmiotowości. Z drugiej strony, mogą powodować nasilenie się poziomu odczuwanego stresu co bezwzględnie będzie prowadziło do zmniejszenia skuteczności działania i poczucia alienacji.

\section{Ramy czasowe tymczasowego kontraktu psychologicznego}

Forma i zawarte treści kontraktu psychologicznego nierozerwalnie związane są z doświadczaniem pracy w perspektywie temporalnej. W przypadku pracowników zatrudnianych przez agencje pracy tymczasowej trudność związana z poczuciem krótkich bądź długich ram czasowych polega w głównej mierze na wspomnianym wcześniej fenomenie „podwójnego pracodawcy". Jest nim bowiem agencja pracy tymczasowej, będąca prawnym i formalnym pracodawcą, a także firma - użytkownik, do której oddelegowany zostaje pracownik i na rzecz której wykonuje on powierzoną mu pracę.

Ramy czasowe pomiędzy pracodawcą a pracownikiem - biorąc pod uwagę nowe trendy w zatrudnieniu - są wyznacznikiem nie tylko nowych kontraktów, ale także alternatywnych układów zatrudnienia pojawiających się w odpowiedzi na bieżące zapotrzebowania pracowników ${ }^{34}$. Pojęcie czasu odnosi się wg. Rousseau i Parks, do długo - lub krótkoterminowej formy zatrudnienia. Ich konceptualizacja kontraktu psychologicznego opiera się na przybieraniu dwojakiego charakteru psychologicznego: otwartego lub krótkoterminowego, przy uwzględnieniu istnienia niewielu relacji zawodowych "na całe życie” ${ }^{35}$.. McLean, Kidder, Gallagher wskazali na dwa składowe elementy ram czasowych zatrudnienia. Pierwszą z nich jest trwałość ram czasowych, będąca przedziałem czasowym, który pracownik postrzega jako krótko- bądź długo-

\footnotetext{
33 Jak wyżej, s. 20.

34 Kissler G. R. The New Employment Contract, Human Resource Management, 1994, s. 335-352.

35 Rousseau D.M., Parks J. M., op.cit. s. 1-47.
} 
okresowy. Drugą składową jest precyzja ram czasowych, która dotyczy zakresu, w którym pracownik postrzega trwałość związku jako skończoną lub nieskończoną ${ }^{36}$.

Spodziewana długość oraz stopień pewności co do terminu zakończenia zaciągniętych zobowiązań mają wpływ na naturę kontraktu psychologicznego. Zestawiając te dwa podwymiary ram czasowych, McLean, Parks, Kidder i Gallagher, stworzyli 4 kategorie: ${ }^{37}$

- krótkie i skończone ramy czasowe tradycyjnie przypisywane pracownikom tymczasowym;

- krótkie i nieskończone, przypisywane pracownikom sezonowym, bądź z listy;

- długie i skończone, swoiste dla niezależnych współpracowników;

- długie i nieskończone, typowe dla pracowników zatrudnionych w oparciu o umowę na czas nieokreślony lub podwykonawców.

Tymczasowy kontrakt psychologiczny nierozerwalnie związany jest z krótszymi, skończonymi ramami czasowymi w porównaniu z kontraktem pracownika zatrudnionego na umowę na czas nieokreślony. Występują pewne różnice pomiędzy zawieranymi kontraktami psychologicznymi w obrębie pracowników tymczasowych, jak i pomiędzy nimi a pracownikami zatrudnionymi w oparciu o umowę na czas nieokreślony. Większość pracowników tymczasowych, wynajęta za pośrednictwem agencji pracy tymczasowej, nie przewiduje dłuższego zatrudnienia w organizacji. Pracownicy wykonujący czasowe, krótkie zlecenia zwyczajowo nie utrzymują emocjonalnego kontaktu z innymi pracownikami danej organizacji, jako, że ci nie mają powodów, by szukać bliskich znajomości wśród pracowników tymczasowych ${ }^{38}$. Pracownicy zatrudnieni w organizacji na stałe często odczuwają brak chęci i motywacji do nawiązywania bliższych kontaktów z pracownikami tymczasowymi, ponieważ ci szybko opuszczają organizację. Ta bariera uniemożliwia pracownikom tymczasowym uzyskanie wsparcia ze strony swoich stałych współpracowników. Jednakże dłuższe zatrudnienie tymczasowe może prowadzić do bliższych interakcji między stałymi a tymczasowymi współpracownikami. Dłuższe tymczasowe zatrudnienie może przyczyniać się do wzrostu identyfikacji z organizacją użytkownikiem, to zaś powoduje wzrost zagrożeń związanych z konfliktem ról pełnionych przez pracownika tym czasowego ${ }^{39}$.

Mimo iż pracownicy tymczasowi mogą być słabiej związani z organizacją i mniej zaznajomieni ze zwyczajami panującymi w pracy od pracowników zatrudnionych na stałe to praca pracownika tymczasowego ma konsekwencje nie tylko dla nich samych, lecz wpływa również na pracę pracowników stałych wpływając na postawy i zachowania w miejscu pracy ${ }^{40}$. Badania Broschaka i Davis-Blake'a potwierdzają występowanie wielu rodzajów układów zależności, jakie tworzą się pomiędzy pracownikami stałymi i czasowymi. Negatywny wpływ na postawy pełnoetatowych pracowników może wywołać np. sytuacja, gdzie pracownicy zatrudnieni na stałe dochodzą do wniosku, że

\footnotetext{
36 McLean Parks J., Kidder D. L., Gallagher D. G.,op.cit., s. 697-730.

37 Jak wyżej, s. 697-730.

38 Rogers J.K., op.cit., s. 137-166.

39 Rogers J.K., op.cit., s. 137-166.

40 Kochan T. A., Smith M., Wells J. C., Rebitzer J. B., Human resource strategies and contingent workers: The case of safety and health in the petrochemical industry. Human Resource Management, 1994, 33, s. 55-77.
} 
organizacja wykorzystuje pracowników tymczasowych ${ }^{41}$. Takie spostrzeżenia skłaniają do podważania uczciwości i wiary rdzennych pracowników w etyczność macierzystej firmy. Tymczasowy charakter umowy o zatrudnienie negatywnie wpływa na chęć inwestowania czasu i wysiłku w pomaganie pracownikom czasowym w proces adaptacji i szkolenia do nowych obowiązków związanych z pełnioną funkcją ${ }^{42}$.

Nawiązanie tymczasowego kontraktu psychologicznego w oparciu o konkretne ramy czasowe z jednej strony zmniejsza niepewność pracownika, ale i może spowodować obniżenie poziomu zaangażowania pracownika w wykonywane obowiązki w miarę kończenia się okresu zatrudnienia. Skonkretyzowane ramy czasowe mogą mobilizować pracownika do zapewnienia sobie kolejnego zlecenia, co może wiązać się ze zmniejszeniem uwagi poświęcanej obecnie wykonywanym zadaniom.

Określanie ram czasowych staje się istotne z punktu widzenia zrozumienia postaw i zachowań pracowniczych w kontekście relacji ze współpracownikami przełożonymi. Cechą wyróżniającą tymczasowe zatrudnienie jest bowiem temporalność, wpływająca na wszelkie aspekty pracy, a mianowicie na "tymczasowo" wykonywane zlecenie, relacje zawodowe, strony kontraktu, status „tymczasowego" pracownika itp. Zmienia to perspektywę patrzenia na przyszłość zawodową pracownika i jego dalsze funkcjonowanie, odmienne od stałego zatrudnienia.

\section{Zakończenie}

Idea człowieka pracującego tymczasowo, związana z perspektywą globalizacji pracy, ma swoje odzwierciedlenie w życiu zawodowym coraz to większej liczby ludzi i odgrywa niebagatelną rolę w kreowaniu poczucia jakości życia. Budowa stosunku zatrudnienia opiera się na nieustannie zachodzących relacjach międzyludzkich, w tym przypadku, na relacjach zachodzących między pracownikiem, pracodawcą a agencją pracy tymczasowej. Nawiązywanie trójstronnych relacji pracy między wspomnianymi podmiotami rozpoczyna się w momencie zawieranego kontraktu psychologicznego. Tymczasowy kontrakt psychologiczny rozpatrywany jest jako niepisany zbiór specyficznych, trójstronnych obietnic, oczekiwań i zobowiązań stron relacjij ${ }^{43}$. Spełnia on dwa podstawowe zadania: definiuje dynamiczne trójstronne relacje oraz stanowi punkt odniesienia zmieniających się wzajemnych oczekiwań, zobowiązań i obietnic.

Tymczasowy kontrakt psychologiczny jest oparty głównie na zasadzie wzajemności oraz skutkach przewidywanego zadowolenia ze spełnionych oczekiwań. Nacisk na zaspokojenie potrzeb tworzy relacje, w których pracownicy próbują i zaspokajają potrzeby agencji i organizacji użytkownika w przypadku, gdy obydwoje pracodawcy zaspokoją potrzeby pracowników. Tak więc, zarówno pracownik jak i obydwoje pracodawcy mają silne oczekiwania wobec siebie, które motywują trzy strony do kon-

41 Broschak J. P., Davis-Blake A., The Divergence of Macro-Structure and Micro-Dynamics: The Effects of Contingent Work and Outsourcing of Workplace Dynamics, Academy of Management Meeting, San Diego, 1998, https://gupea.ub.gu.se/bitstream/2077/4223/1/ah1999_07.pdf. [dostęp z dn. 13.07.2013].

42 Kochan T. A., Smith M., Wells J. C., Rebitzer J. B., op. cit., s. 33, 55-77.

43 Rousseau D. M., Tijoriwala, S., Assessing psychological contracts: issues, alternatives and measures. Journal of Organizational Behavior,1998, s.121-139. 
tynuowania tej relacji. W trakcie trwania tymczasowego kontraktu psychologicznego wzajemnie kreowane oczekiwania mogą ulec zmianie, ponieważ strony negocjują zmiany oczekiwań, które mogą wyniknąć ze zmian w okolicznościach lub pełniejszego zrozumienia wkładu jednej ze stron relacji.

Zgromadzony w niniejszym opracowaniu materiał pozwolił podjąć próbę określenia psychologicznych uwarunkowań zachowania się ludzi wykonujących pracę na zasadzie zatrudnienia tymczasowego, a przede wszystkim określenia ram czasowych kontraktu psychologicznego oraz odczuwanej satysfakcji z pracy i ponoszonych kosztów psychologicznych. Pozwoliło to na lepsze zrozumienie mechanizmów regulacyjnych funkcjonowanie człowieka w tych warunkach pracy. Wyżej nakreślone aspekty pracy tymczasowej to integralne elementy tymczasowego kontraktu psychologicznego, ważne dla rozumienia funkcjonowania pracownika w warunkach tymczasowego zatrudnienia.

\section{Bibliografia}

Bohdziewicz P., Kariery zawodowe w gospodarce opartej na wiedzy (na przykładzie grupy zawodowej informatyków), Wydawnictwo UŁ, Łódź, 2008.

Brief A., Burke M., George J., Robinson B., Webster J., Should Negative Affectivity Remain an Unmeasured Variable in the Study of Job Stress?, Journal of Applied Psychology", 1988, 73.

Broschak J. P., Davis-Blake A., The Divergence of Macro-Structure and Micro-Dynamics: The Effects of Contingent Work and Outsourcing of Workplace Dynamics, Academy of Management Meeting, San Diego, 1998, https://gupea.ub.gu.se/bitstream/2077/4223/1/ah1999_07.pdf. [dostęp z dn. 13.07.2013].

Conway N., Briner R. B., Understanding Psychological Contract at Work, OUP, Oxford, 2002.

Cullinane, N., Dundon, T., The psychological contract: A critical review. International Journal of Management Reviews, 2006,8 (2).

Cuyper, N., DeWitte, H., The impact of job insecurity and contract type on attitudes, well-being and behavioural reports: A psychological contract perspective. Journal of Occupational and Organizational Psychology, 2006,79.

Diener E., Larsen R.J., Emmons R.A., Person \& Situation interactions: Choice of situations and congruence response models. Journal of Personality and Social Psychology, 1984, 47.

Eisenhardt K., Agency theory: An assessment and review. Academy of Management Review, 1989, 14.

Fieldman D., Doerpinghaus H., Turnley W., Managing Temporary Workers: A Permanent HRR Challange, Organizational Dynamics, 1994, 23.

Guest D., Flexible employment contracts, the psychological contract and employee outcomes: an analysis and review of the evidence. International Journal of Management Reviews, 2004,5/6.

Hiltrop J. M., The changing psychological contract: the human resource challenge of the 1990s, European Management Journal, 1995, 13(30).

Judge T.A., Locke E.A., Durham C.C., Kluger A.N., Dispositional Effects on Job and Life Satisfaction: The Role of Core Evaluations, Journal of Applied Psychology, 1998, 83.

Kissler G. R., The New Employment Contract, Human Resource Management, 1994.

Kochan T. A., Smith M., Wells J. C., Rebitzer J. B., Human resource strategies and contingent workers: The case of safety and health in the petrochemical industry. Human Resource Management, 1994, 33.

Larsen R.J., Ketelaar T., Personality and susceptibility to positive and negative emotional states. Journal of Personality and Social Psychology, 1991, 61.

McLean Parks J., Kidder D. L., Gallagher D. G., Fitting square pegs into round holes: mapping the domain of contingent work arrangements onto the psychological contact. Journal of Organizational Behavior, 1998, 19.

Pfeffer J., Baron J. N., Talking the workers back out: Recent trends in the structure of employment. In: Cummings L. L., Staw B. M., (Eds.), Research in Organizational Behavior, Rights and Responsibilities Journal, 1988, 2. 
Raja, U., Johns, G., Ntalianis F., The impact of personality on psychological contracts. Academy of Management Journal, $2004,47$.

Ratajczak Z., Wsparcie społeczne w warunkach zagrożenia funkcjonowania człowieka w środowisku pracy, Psychologiczne problemy funkcjonowania człowieka w sytuacji pracy, Uniwersytet Śląski, 1992, 10.

Rogers J.K., Just a temp: experience and structure of alienation in temporary clerical employment, Work and Occupations, 1995, 22, (2).

Rogozińska-Pawełczyk A., Od relacyjnego do transakcyjnego kontraktu psychologicznego - zmieniający się paradygmat, Zarządzanie Zasobami Ludzkimi, 2011,3-4.

Rogozińska-Pawełczyk A., Impact and effects of relational and transactional psychological contract. Slovak Scientific Journal Management: Science and Education, Faculty of Management Science and Informatics, University of Žilina, 2012, Vol.1 no.1.

Rousseau D. M., Psychological Contracts in Organizations: Understanding Written and Unwritten Agreements, Sage, Thousand Oaks-London, 1995.

Rousseau D.M., Parks J. M., The contract of individuals and organizations. In: Cummings L. L., Staw B. M., (Eds), Research in organizational behavior, 1993, Vol. 15, Greenwich, CT: JAI Press.

Rousseau D. M., Tijoriwala, S. Assessing psychological contracts: issues, alternatives and measures. Journal of Organizational Behavior, 1998.

Rousseau D.M. Schema, promises and mutuality: the building blocks of the psychological contract. Journal of Occupational and Organisational Psychology, 2001, 74 (4).

Schein V.E., Maurer E.H., Novak J.F., Impact of flexible working hours on flexibility. Journal of Applied Psychology, 1977, 62, 463-465, za: Armstrong M., Zarządzanie zasobami ludzkimi, Wolters Kluwers, 2007, Kraków.

Sutton, G., Griffin, M., Integrating expectations, experiences and psychological contract violations: A longitudinal study of new professionals. Journal of Occupational and Organizational Psychology, 2004,77.

Tilly Ch., Reasons for the Continuing Groth in Part-Time Employment. Monthly Labour Review, 1991, 3. 